\title{
Net Greenhouse Gas Emissions Savings from Natural Gas Substitutions in Vehicles, Furnaces, and Power Plants
}

Daniel S. Cohan* and Shayak Sengupta, Department of Civil and Environmental Engineering, Rice University, 6100 Main Street MS 519, Houston, TX 77005 USA

*Corresponding author: 1-713-348-5129; cohan@ rice.edu

\begin{abstract}
We compare the net greenhouse gas emissions impact of substituting natural gas for other fossil fuels for five purposes: light-duty vehicles, transit buses, residential heating, electricity generation, and export for electricity generation overseas. Emissions are evaluated on a fuel cycle basis, from production and transport of each fuel through end use combustion, based on recent conditions in the United States. To compare across sectors, the emissions difference between natural gas and its alternative is normalized by natural gas consumption to compute the net reduction in $\mathrm{CO}_{2} \mathrm{e}$ per $\mathrm{MJ}$ of natural gas used. Greatest emission reductions can be achieved by replacing existing coal-fired power plants ( $78 \mathrm{~g} \mathrm{CO}_{2}-\mathrm{e} / \mathrm{MJ}$ natural gas) or fuel oil furnaces (66 $\left.\mathrm{gCO}_{2} \mathrm{e} / \mathrm{MJNG}\right)$. Compressed natural gas in vehicles yields no significant reductions.

Uncertainties arising from upstream emission rates for natural gas and the global warming potential of methane are quantified. The study demonstrates the critical role of deployment choice on the net climate impact of natural gas.
\end{abstract}

Keywords: Fuel cycle analysis; natural gas deployment; greenhouse gas emissions; methane; carbon dioxide; attributional life cycle analysis; upstream emissions; break-even leak rate 


\section{Introduction}

Recent advances in drilling technologies, including hydraulic fracturing and horizontal drilling, have vastly expanded the availability of natural gas resources. Marketed natural gas production in the United States has grown from 18.9 trillion cubic feet (tcf) in 2005 to 27.3 tcf in 2014 (U.S. Energy Information Administration (EIA)). By 2040 under current policies, U.S. natural gas production is expected to grow by 39 percent [US-EIA, 2015a], while global natural gas demand is expected to grow by 69 percent [IEA, 2014].

A distinct feature of natural gas is that its use is spread across the sectors of the energy economy [IEA, 2011; US-EIA, 2015a; b], in contrast to oil (used primarily for transportation) or coal (used primarily for electricity generation). Electricity generation is the leading sector of U.S. natural gas consumption, and most of the increased consumption to date has reflected a shift from coal to natural gas power plants [US-EIA, 2015a]. Meanwhile, natural gas is the most widely used fuel for residential space heating [US-DOE, 2012b], competing primarily with electric heat pumps in some regions and replacing fuel oil furnaces in others. However, percentage growth rates are expected to be fastest in the transportation sector, where natural gas substitutes for petroleum-based fuels [US-EIA, 2015a]. Another use with potentially rapid growth is liquefied natural gas (LNG) for export, as the U.S. Department of Energy considers dozens of applications to export LNG [GAO, 2014].

The distribution of natural gas across these uses will be influenced not only by market forces but also by various existing and proposed policies. The U.S. Environmental Protection Agency (EPA) has proposed rules for $\mathrm{CO}_{2}$ emissions from new and existing power plants that are expected to accelerate the shift from coal to natural gas [US-EPA, 2013b;2014a]. These power 
plant rules are part of an overall effort to mitigate greenhouse gas (GHG) emissions nationally. Meanwhile, in the U.S. Congress, legislative proposals have sought to spur greater use of natural gas for transportation (H.R. 1380: New Alternative Transportation to Give Americans Solutions Act of 2011) or to foster increased exports (S. 192: Expedited LNG for American Allies Act of 2013). At the state and local level, some states provide financial incentives for replacing old fuel oil furnaces with new natural gas furnaces, and some transit agencies have committed to purchasing compressed natural gas $(\mathrm{CNG})$ buses.

The myriad of policies that may affect natural gas deployment across sectors provides impetus for assessing how different uses of natural gas may impact greenhouse gas emissions. Broad-scale energy systems modeling studies have projected that more abundant natural gas will only slightly impact aggregate greenhouse gas emissions, as the benefits of replacing dirtier fossil fuels are offset by the displacement of nuclear and renewables and the stimulation of energy consumption due to lower prices [McJeon et al., 2014; Newell and Raimi, 2014]. While these economy-wide studies attempt to project the overall response of energy systems to growing availability of natural gas, direct substitution studies are needed to quantify the net emissions impacts of specific natural gas substitutions and thereby inform policies that could influence those substitutions. Three direct substitution studies all showed far more favorable net impacts for replacing coal-fired electricity than for replacing gasoline or diesel vehicles [Alvarez et al., 2012; A. Burnham et al., 2012; Venkatesh et al., 2011b]. However, residential uses and exports of natural gas were not considered in those comparisons.

Here, we conduct direct substitution analyses for a larger range of natural gas deployment options than has been considered previously, including home heating and exports along with vehicles and power plants that have been more widely studied. Substitutions are evaluated based 
on recent conditions in the United States, using the metric of grams $\mathrm{CO}_{2}$ equivalent reduced per megajoule of natural gas consumed $\left(\mathrm{gCO}_{2} \mathrm{e} / \mathrm{MJNG}\right)$ [Venkatesh et al., 2011b] to facilitate comparisons across sectors. We quantify how results vary with alternate assumptions for the "upstream" emission rates from natural gas production and transport, given the substantial uncertainty in the rate of methane $\left(\mathrm{CH}_{4}\right)$ leakage and other emissions from natural gas production [Allen et al., 2013; Howarth et al., 2011; Petron et al., 2012; US-EPA, 2013a] and from distribution infrastructure [Alvarez et al., 2012; Jackson et al., 2014; Lamb et al., 2015; McKain et al., 2015; Peischl et al., 2013; Phillips et al., 2013; Wennberg et al., 2012]. Thus, our results will show how the net greenhouse gas emissions impacts of natural gas depend on both uncertainty in upstream emissions and deployment choices, considering a wider range of substitutions than previous studies.

\section{Methods}

Five possibilities for the substitution of U.S. produced natural gas for other fossil fuels are considered here: (1) compressed natural gas $(\mathrm{CNG})$ to replace gasoline for light-duty vehicles, (2) CNG to replace diesel for transit buses, (3) natural gas furnaces to replace heating oil furnaces or electric heat pumps for residential heating, (4) natural gas to replace coal for domestic electricity generation, and (5) shipment of liquefied natural gas (LNG) to replace coal for electricity generation in Japan. These options were chosen because electric power and residential are the first and third largest sectors of U.S. natural gas consumption, respectively [US-EIA, 2015b], and because of the large potential for growth in use by the transportation sector [US-EIA, 2015a] and LNG export [GAO, 2014], with Japan by far the world's leading importer of LNG [International_Gas_Union, 2014]. Although non-electric industries are the second 
largest sector of consumption [US-EIA, 2015b], this comprises a wide range of uses that is less readily assessed as substitutions.

In each scenario, we compute the average emission rates for each option to provide the same energy service (e.g., vehicle mile traveled (VMT) or kWh electricity generated). This contrasts to consequential life cycle analysis, which incorporates economic modeling to characterize the marginal unit displaced along with rebound effects and other factors [Earles and Halog, 2011], or energy systems modeling of broad-scale shifts across sectors [McJeon et al., 2014; Newell and Raimi, 2014]. Our approach is instead consistent with and expands upon the options considered in previous attributional fuel cycle analyses [Alvarez et al., 2012; A. Burnham et al., 2012; Venkatesh et al., 2011b], and is best suited for direct comparison of specific uses and technologies.

For consistency across sectors, we focus our evaluations on the complete fuel cycle (i.e., "well-to-wheels" or "well-to-wires"), including emissions from the production and distribution of the fuel and its end use combustion (Figure 1). Note that compression is needed only for the CNG vehicles, and that power plants are assumed to avert local distribution by obtaining natural gas from major pipelines. Consistent with previous fuel cycle analyses, our scope excludes manufacture or disposal of vehicles, furnaces, or power plants and the construction of pipeline or refueling infrastructure. Data are expressed per MJ higher heating value, except where otherwise noted. $\mathrm{CO}_{2}$ equivalent emissions are computed by scaling methane and nitrous oxide by 36 and 298 (100-year global warming potentials (GWP) from IPCC [IPCC, 2013]), respectively. The methane GWP reflects an increase from earlier IPCC estimates, in part because the latest IPCC report recommends inclusion of climate-carbon feedbacks and the oxidation of fossil fuel methane to $\mathrm{CO}_{2}$. 
The Greenhouse gases, Regulated Emissions, and Energy use in Transportation (GREET) model [A Burnham et al., 2006] was used to compare light-duty vehicles, as detailed in Section 2.1. Since GREET focuses on light-duty vehicles, all other scenarios were assessed via offline analysis as detailed in Sections 2.2-2.5 and Table 1. Upstream emission estimates were taken primarily from a series of papers by Venkatesh et al. for natural gas, coal, and petroleum-based fuels [Venkatesh et al., 2011a; b; 2012], and from Abrahams et al. (2015) for LNG (Table 1). These papers were chosen for their consistency of methods across fuels and because they quantified $5^{\text {th }}-95^{\text {th }}$ percentile uncertainty ranges. The baseline emission estimates from the Venkatesh papers are sufficiently similar to the GREET inputs that they would have yielded differences of only 0-3\% if used for the light-duty vehicle calculations.

The Venkatesh estimates for methane emissions from upstream processes are equivalent to a natural gas leak rate of $2.2 \%(1.5-3.0 \%)$. This range encompasses the leak rate estimates from most recent studies [A. Burnham et al., 2012; Hultman et al., 2011; Jiang et al., 2011], including a 1.7\% leak rate in the latest U.S. EPA inventory [US-EPA, 2014b]. Most studies based on atmospheric measurements have estimated overall U.S. methane emissions to be about $1.25-$ 1.75 times the EPA inventory [Brandt et al., 2014], although the ratio specific to natural gas emissions is uncertain.

\subsection{Light-duty Vehicles}

Comparisons for CNG- and gasoline-powered light-duty vehicles were conducted with the December 2012 release of GREET, a life cycle model developed by Argonne National Laboratory for estimating the emissions and energy use of vehicles [A Burnham et al., 2006]. GREET consists of two components to cover the full life cycle of a vehicle and the fuel that it 
uses. The fuel cycle model computes "well-to-wheels" energy use and emissions per mile of vehicle use, accounting for "well-to-pump" processes of fuel extraction, processing and distribution along with "pump-to-wheels" operation of the vehicle. The vehicle cycle model computes energy and emissions associated with the manufacture and disposal of a vehicle. The vehicle cycle model does not distinguish between $\mathrm{CNG}$ and gasoline vehicles, and estimates that manufacture of a gasoline hybrid vehicle generates only $2 \mathrm{~g} / \mathrm{km}$ more $\mathrm{CO}_{2} \mathrm{e}$ than a conventional vehicle (assuming a 260,000 $\mathrm{km}$ vehicle lifetime). Since this difference in vehicle cycle emissions is small compared to differences in fuel cycle emissions, and to maintain consistency with our substitution scenarios in other sectors, only fuel cycle emissions are considered here.

Because of its availability in gasoline, gasoline hybrid, and CNG form, the Honda Civic was chosen as the basis for comparison, with fuel economy taken from www.fueleconomy.gov for Model Year 2013 (Table 1). In-use methane leaks (including driving and refueling) from the CNG vehicle were assumed to be $0.6 \%$ [Alvarez et al., 2012; Victor, 1992]. Other inputs were taken from the Year 2015 default conditions of the December 2012 release of GREET.

\subsection{Transit Buses}

Fuel economy estimates for $\mathrm{CNG}$ and diesel powered 40-foot transit buses were taken from a National Renewable Energy Laboratory survey of U.S. transit agencies (Table 1) [NREL, 2010]. The survey found a $20 \%$ efficiency penalty for CNG relative to diesel and a similar $21 \%$ penalty in 60-foot buses, but noted claims by manufacturers that new $\mathrm{CNG}$ engines can achieve penalties of $10 \%$ or less. The penalty refers to the shorter distance traveled by CNG buses than diesel buses per gallon of diesel equivalent, assuming 1.37 therms CNG per gallon of diesel. Upstream and combustion emission rates for each fuel were taken from the Venkatesh studies (Table 1). 


\subsection{Residential Heating}

We consider three options for residential heating: natural gas furnaces, fuel oil furnaces, and electric heat pumps. New furnaces are assumed to meet the Energy Star standards for annual fuel utilization efficiency (AFUE) for non-weatherized furnaces: 95\% for natural gas and 85\% for fuel oil (Table 1). We also consider the scenario of a new natural gas furnace replacing a fuel oil furnace from the 1970s, when AFUE of roughly 65\% was typical [US-DOE, 2012a]. Fuel cycle emissions per unit of natural gas or fuel oil consumed are taken from the Venkatesh studies as shown in Table 1.

Electric heat pumps are assumed to meet the EnergySTAR Heating Seasonal Performance Factor (HSPF) of 8.0 Btu per kWh consumed. Electric furnaces with an AFUE of $95 \%$ would use more than 2.5 times as much electricity as these electric heat pumps and thus are not considered to be a competitive option. Fuel cycle emissions of consumed electricity are developed by obtaining national average direct emissions for electricity from U.S. EPA's eGRID2012 version 1.0 for Year 2010 (www.epa.gov/egrid). Line losses of $6.2 \%$ from transmission and distribution are assumed (EGRID), and upstream emissions for the natural gas and coal used for electricity generation are taken from the Venkatesh studies. This approach yields a very similar estimate of fuel cycle emissions from electricity as the GREET model $\left(685 \mathrm{gCO}_{2} \mathrm{e} / \mathrm{kWh}\right.$ consumed, vs. 688 in GREET), but allows for sensitivity analysis by considering electricity from different eGRID regions. On this basis, fuel cycle electricity emissions range from $385 \mathrm{gCO}_{2} \mathrm{e} / \mathrm{kWh}$ consumed in the Northeast Power Coordinating Council to 867 in the Southwest Power Pool.

\subsection{Domestic Electricity Generation}


Fuel cycle emissions are compared for both existing and new natural gas and coal-fired power plants. For existing facilities, direct emission rates $\left(983 \mathrm{gCO}_{2} \mathrm{e} / \mathrm{kWh}\right.$ for coal, 429 $\mathrm{gCO}_{2} \mathrm{e} / \mathrm{kWh}$ for natural gas, almost all of it as $\mathrm{CO}_{2}$ ) and heat rates (Table 1) are taken from eGRID2012 national average data for Year 2010 (www.epa.gov/egrid). Upstream emissions are computed by multiplying the eGRID heat rates by the upstream emission rates and uncertainty ranges from Venkatesh. Heat rates for new natural gas advanced combined cycle and coal power plants coming online in 2015-2017 are taken from the assumptions used in the Electricity Market Module for U.S. DOE's Annual Energy Outlook 2014 [US-EIA, 2014a]. Direct and upstream emissions for these facilities are computed by scaling the existing facility results by the ratio of the heat rates of new and existing facilities.

\subsection{Export for Overseas Electricity Generation}

Although the U.S. has historically been an importer of LNG, the growing abundance of natural gas has prompted dozens of proposals to construct LNG export terminals, most of them proposing sites on the Texas or Louisiana coast [GAO, 2014]. We consider export of LNG from the Sabine Pass Louisiana LNG Terminal, the first terminal approved by US DOE for export by LNG tanker [GAO, 2014]. The LNG is assumed to be shipped to Japan, the world's largest importer of LNG [International_Gas_Union, 2014]. Thermal efficiencies (48.3\% for natural gas; $41.3 \%$ for coal $)$ and direct emission rates $\left(411 \mathrm{gCO}_{2} \mathrm{e} / \mathrm{kWh}\right.$ for natural gas; $825 \mathrm{gCO}_{2} \mathrm{e} / \mathrm{kWh}$ for coal) for Japanese power plants are taken from Ecofys data for 2010 (Table 1) [Ecofys, 2013], the most recent year available. Emissions estimates for LNG production, liquefaction, shipping, and regasification (Table 1) are taken from a recent study which focused specifically on life cycle emissions for LNG exports from the U.S. to Japan and other countries [Abrahams et al., 2015]. . Transport of natural gas and coal within Japan is neglected. 
Coal is assumed to be obtained from Australia, with overseas transport emissions taken from [Hardisty et al., 2012] for Australia-China coal export, scaled based on the heat rate of Japanese power plants and the approximately $20 \%$ longer travel distance to Japan. This yields an overseas transport estimate of $32.1 \mathrm{gCO}_{2} \mathrm{e}$ per $\mathrm{kWh}_{\mathrm{e}}$, which is added to the emission rates for other processes.

\section{Results and Discussion}

\subsection{Comparisons within Sectors}

Vehicle options are first compared on the basis of well-to-wheels emissions per kilometer driven. GREET estimates that well-to-wheels emissions for a CNG Civic and a conventional gasoline Civic are each $220 \mathrm{gCO}_{2} \mathrm{e} / \mathrm{km}$ (Figure 2). The lower tailpipe emissions from the $\mathrm{CNG}$ Civic are offset by its leaks of methane in-use and upstream (Figure 2). The hybrid gasoline Civic achieves 27\% lower well-to-wheels emissions than the CNG or conventional gasoline options, due to its better fuel economy. The emissions estimates for the CNG and gasoline vehicles are consistent with those reported by [A. Burnham et al., 2012], adjusted for the fuel economy of the newer model year considered here and the higher GWP for methane. Our estimate of equal emissions from CNG and conventional gasoline cars contrasts with [Luk et al., 2015], who reported $20 \%$ lower GHG emissions from CNG. However, that study assumed a lower GWP for methane, a lower in-use leak rate for natural gas, and that CNG vehicles achieve better fuel economy than gasoline vehicles, contradicting the opposite pattern shown for Honda Civics in U.S. EPA data (www.fueleconomy.gov, last accessed July 21, 2015).

We can assess the extent to which the emissions estimates depend on uncertain upstream emission rates by considering the $5^{\text {th }}-95^{\text {th }}$ percentile range for upstream processes for both natural 
gas and petroleum from the Venkatesh papers [Venkatesh et al., 2011a; b] (Table 1). This leads to overall well-to-wheels emissions estimate ranges of 206-241 $\mathrm{gCO}_{2} \mathrm{e} / \mathrm{km}$ for gasoline, 197-253 $\mathrm{gCO}_{2} \mathrm{e} / \mathrm{km}$ for $\mathrm{CNG}$, and $150-176 \mathrm{gCO}_{2} \mathrm{e} / \mathrm{km}$ for the hybrid Civic (error bars in Figure 2). Thus, while the hybrid achieves the lowest emissions, the differences between $\mathrm{CNG}$ and conventional gasoline are well within the uncertainty of upstream emissions. That differences between GHG emissions of CNG and conventional gasoline vehicles are within the uncertainty of input assumptions is consistent with other studies [Alvarez et al., 2012; A. Burnham et al., 2012; Venkatesh et al., 2011b].

For buses, our analysis using the baseline data from Table 1 estimates that CNG buses emit $12 \%$ more well-to-wheels $\mathrm{CO}_{2} \mathrm{e}$ than diesel, as the efficiency penalty of $\mathrm{CNG}$ more than offsets its smaller carbon footprint per joule (Figure 2). This difference in emissions is within the $5^{\text {th }}$ $95^{\text {th }}$ percentile range of upstream emissions indicated by the error bars in Figure 2. If new technology can indeed narrow the efficiency penalty from $20 \%$ to $10 \%, \mathrm{CNG}$ would achieve a baseline emission rate nearly identical to diesel. Our results are consistent with a recent study that found the 100-year GHG impacts of CNG and diesel trucks to be very similar, with the ranking depending on the assumptions for efficiency penalty (the study considered a 0-20\% range) and natural gas leak rate (0-4\% range) [Camuzeaux et al., 2015].

Residential heating options are evaluated in terms of fuel cycle emissions per MJ of heat supplied to the home. Since natural gas furnaces achieve higher efficiency than fuel oil while using a less carbon-intensive fuel, their emissions are substantially lower (Figure 3). Natural gas furnaces meeting the Energy Star standard emit roughly $32 \%$ less greenhouse gases than their fuel oil counterparts under baseline assumptions. Even greater emission reductions (48\%) can be achieved by replacing an old fuel oil furnace with an Energy Star natural gas furnace. All of 
these savings are well beyond the $5^{\text {th }}-95^{\text {th }}$ percentile uncertainty range associated with upstream emissions for fuel oil and natural gas [Venkatesh et al., 2011a; b] (error bars in Figure 3).

Emission rates are much closer for natural gas furnaces and electric heat pumps. Based on national average electricity conditions described in Section 2.3, fuel cycle $\mathrm{CO}_{2} \mathrm{e} / \mathrm{MJ}_{\text {heat }}$ emission rates for Energy Star electric heat pumps (81 g) are within the range of estimates for Energy Star natural gas furnaces given uncertainty in upstream natural gas emissions (74 $\mathrm{g}$ best estimate; $66-$ $83 \mathrm{~g}$ range). As noted in Section 2.3, emission rates for electricity generation vary by more than a factor of two between electric power markets. An electric heat pump powered by electricity from the Northeast Power Coordinating Council would be estimated to generate $46 \mathrm{gCO}_{2} \mathrm{e} / \mathrm{MJ}_{\text {heat }}$, compared to $111 \mathrm{gCO}_{2} \mathrm{e} / \mathrm{MJ}_{\text {heat }}$ for the Southwest Power Pool. Climatic differences would also affect the performance of the electric heat pumps, which achieve greatest efficiency in moderate temperatures. Furthermore, emissions rates for electricity are likely to decline with time under U.S. EPA proposed policies limiting emissions from new and existing power plants [US-EPA, 2013b; 2014a]. Thus, the relative emissions of natural gas furnaces and electric heat pumps will vary strongly with location and time.

Power plant options are evaluated in terms of fuel cycle ("well-to-wire") emissions per kWh of electricity generated, based on the assumptions in Section 2.4 and Table 1. Emissions from Year 2010 natural gas fired electricity are estimated to be 608 (548-676) $\mathrm{gCO}_{2} \mathrm{e} / \mathrm{kWh}$ compared to 1068 (1004-1218) for coal, where the uncertainty ranges reflect the $5^{\text {th }}-95^{\text {th }}$ percentile upstream rates (Figure 4). This substantial emissions savings for natural gas results from its lower carbon intensity and greater efficiency for generating electricity. Based on the lower heat rates expected to be achieved by new power plants (Table 1), we estimate that well-to-wire emission rates would be 487 (439-542) $\mathrm{gCO}_{2} \mathrm{e} / \mathrm{kWh}$ for advanced combined cycle natural gas, 
and 896 (842-1021) for coal without carbon capture (Figure 4). However, the new coal facility modeled here would not meet EPA-proposed New Source Performance Standards for $\mathrm{CO}_{2}$ [US$E P A, 2013 b]$, and unfavorable cost competitiveness is curtailing development of new coal generation [US-EIA, 2014b; US-EPA, 2012b]. Thus, new natural gas power plants would most likely displace electricity from existing coal facilities, representing an emissions savings of more than a factor of two.

Electricity generated in Japan from U.S. exported LNG is estimated to have a fuel cycle emission rate of $790(644-935) \mathrm{gCO}_{2} \mathrm{e} / \mathrm{kWh}$ (Figure 4). Here, the range reflects the $5^{\text {th }}-95^{\text {th }}$ percentile range from for natural gas production and LNG-specific processes (liquefaction, shipping, and regasification) from [Abrahams et al., 2015] (Table 1). The base estimate represents a $15 \%$ emission saving relative to our base estimate for Japanese coal-fired electricity generation, as the greater efficiency and lower carbon intensity of natural gas relative to coal more than offsets the emissions associated with LNG processes.

\subsection{Comparisons across Sectors}

Computing the net amount of emission reduction per unit of natural gas used $\left(\mathrm{gCO}_{2} \mathrm{e} / \mathrm{MJNG}\right)$ allows for meaningful comparisons of net impacts for alternate deployments of natural gas across sectors. We define natural gas use in terms of the amount directly consumed by the car, bus, furnace, power plant, or export liquefaction facility. This neglects natural gas use that is embedded in the production, processing, and transport of each fuel, but allows for more straightforward comparisons on a delivered to consumer basis. We focus our uncertainty analysis on the impact of uncertainty in natural gas upstream emissions, using the Venkatesh and Abrahams $5^{\text {th }}-95^{\text {th }}$ percentile ranges described above and in Table 1. Uncertainty in other fuels is 
ignored, to focus attention on natural gas upstream emissions that are an active area of scientific research and a potential target for abatement measures.

Use of natural gas in power plants or furnaces yields far greater emission savings than the CNG vehicle options (Table 2 and Figure 5). This occurs primarily because furnaces and power plants use natural gas more efficiently than other fuels, whereas CNG vehicles are less efficient than their petroleum-fueled counterparts and require local distribution and compression of natural gas. Estimated savings from replacing existing coal-fired electricity with natural gas are 78 (71-85) $\mathrm{gCO}_{2} \mathrm{e} / \mathrm{MJNG}$ for new combined cycle plants, and 50 (42-56) $\mathrm{gCO}_{2} \mathrm{e} / \mathrm{MJNG}$ for existing power plants. Natural gas is estimated to save 34 (25-41) $\mathrm{gCO}_{2} \mathrm{e} / \mathrm{MJNG}$ in comparisons of new residential furnaces meeting Energy Star standards (Table 2). Even greater reductions, 66 (58-74) $\mathrm{gCO}_{2} \mathrm{e} / \mathrm{MJNG}$, could be achieved by using Energy Star natural gas furnaces to replace old oil furnaces (Table 2). However, natural gas furnaces save only 8 (-2-19) $\mathrm{gCO}_{2} \mathrm{e} / \mathrm{MJNG}$ relative to electric heat pumps on a national average basis, due to the high efficiency of that option. As noted in the previous section, emissions associated with electric heat pumps are likely to vary substantially by region and over time.

The sign of the net emissions impact for CNG Civics or buses is each within the uncertainty range from upstream natural gas processes (Table 2 and Figure 5). Our base estimate of nearly identical emissions for the CNG and conventional gasoline Civic (Table 2) is consistent with the estimate from [Venkatesh et al., 2011b] that CNG would save a slight $6 \mathrm{gCO}_{2} \mathrm{e} / \mathrm{MJNG}$, with the difference arising from our assumption of a higher GWP for methane and a higher in-use methane leak rate from $\mathrm{CNG}$ vehicles. We estimate that $\mathrm{CNG}$ buses emit about $9 \mathrm{gCO}_{2} \mathrm{e} / \mathrm{MJNG}$ more on a life cycle basis than diesel buses under base assumptions, within the uncertainty range 
of upstream emissions, and that this difference would disappear if the efficiency penalty for CNG can indeed be reduced from $20 \%$ to $10 \%$.

The one vehicular use of natural gas that could yield substantial savings of $\mathrm{CO}_{2} \mathrm{e}$ emissions would be to power vehicles with electricity generated from natural gas. Based on a 2013 Nissan Leaf electric vehicle, GREET computes emission savings of 41 or $52 \mathrm{gCO}_{2} \mathrm{e} / \mathrm{MJNG}$ relative to a conventional gasoline Civic if the electricity originates from existing natural gas power plants or new combined cycle facilities, respectively. The emission savings would be far smaller (13 or 20 $\mathrm{gCO}_{2} \mathrm{e} / \mathrm{MJNG}$, respectively) if the electric Leaf is instead compared to a hybrid gasoline Civic. Greater emissions associated with manufacturing the electric vehicle and its battery would cut these savings by 4 or $3 \mathrm{gCO}_{2} \mathrm{e} / \mathrm{MJNG}$ relative to the conventional or hybrid vehicle, respectively, based on GREET2 vehicle cycle model calculations for a 260,000 km lifespan. The limited range and smaller size of the Leaf relative to the Civic make this an inexact substitution in terms of operating characteristics. However, the scenario highlights a more efficient potential path for powering vehicles with natural gas.

\subsection{Additional Uncertainty Analyses}

While the uncertainty ranges presented in Table 2 and Figure 5 represent the influence of $5^{\text {th }}$ $95^{\text {th }}$ percentile estimates for natural gas upstream emissions under a methane GWP of 36 , some other studies have specifically quantified the methane leak rates from natural gas or used alternate GWP for methane. Thus, it can be informative to consider the sensitivity of results to assumptions of methane leak rates and methane GWP.

The methane emissions from natural gas that have been assumed so far (Table 1) are equivalent to a $2.0 \%(1.4-2.7 \%)$ leak rate from production and processing and $0.2 \%(0.1-0.5 \%)$ 
from local distribution. Based on our assumed methane GWP of 36 and an assumption that methane constitutes $93 \%$ of delivered natural gas [Alvarez et al., 2012], each one percentage point change in leak rate is equivalent to $6.4 \mathrm{gCO}_{2} \mathrm{e} / \mathrm{MJNG}$. Changes in the assumed leak rate from production and processing affect scenarios uniformly by this factor, whereas power plants avert local distribution and thus are unaffected by that component.

Applying these adjustments, leak rates of 2.2\% and 0.9\% (not including the assumed $0.6 \%$ in-use leak rate from vehicles) would represent the break-even points for CNG to achieve lower fuel cycle emissions than conventional gasoline cars and diesel buses, respectively (Table 2). This is consistent with the findings of Alvarez et al. (2012), who put the break-even points at $3.8 \%$ and $1.7 \%$, respectively, while assuming a lower GWP of 25 for methane. For the furnace and electricity scenarios, natural gas would retain its emission advantage even if assumed overall leak rates were more than tripled (Table 2).

The ranges of methane leak rates to consider remain a subjective choice. For production and processing, the Venkatesh-based range (1.4-2.7\%) encompasses the baseline estimates of most other studies [Brandt et al., 2014; A. Burnham et al., 2012; Jiang et al., 2011; Stephenson et al., 2011; US-EPA, 2014b], but is below the approximately $4 \%$ leak rate from production-only for a field study in Colorado [Petron et al., 2012] or the 3.6-7.9\% estimated by Howarth [Howarth et al., 2011]. As noted earlier, the latest U.S. EPA inventory [US-EPA, 2014b] estimates a 1.7\% leak rate, but most studies based on atmospheric measurements have estimated overall U.S. methane emissions to be about $1.25-1.75$ times the EPA inventory [Brandt et al., 2014]. For local distribution, the Venkatesh estimate $(0.2 \%)$ is consistent with U.S. EPA inventories and [Lamb et al., 2015], but far less than indicated by some other studies [Jackson et al., 2014; Phillips et al., 2013; Wennberg et al., 2012], including an estimate of up to 2.5-6\% for Los 
Angeles [Wennberg et al., 2012]. Substituting a 2.5\% local distribution leak rate for the $0.2 \%$ assumed here would cut emission savings estimates in Table 2 by $15 \mathrm{gCO}_{2} \mathrm{e} / \mathrm{MJNG}$ for the affected scenarios (i.e., furnaces and any $\mathrm{CNG}$ refueling stations that require local distribution). Thus, alternate assumptions for local distribution leaks could substantially influence the relative performance of scenarios across sectors.

The choice of the global warming potential for methane can also impact results. Here, we have adopted the convention of using 100-year GWP, and used the latest available estimate of 36 recommended by IPCC (2013), which includes the carbon-climate feedback and oxidation of fossil fuel methane to $\mathrm{CO}_{2}$. However, many analyses and emission inventories by U.S. EPA and others continue to use the 100-year GWP of 25 from the previous IPCC assessment (2007), or neglect the carbon-climate feedback when applying the GWP value from the latest IPCC assessment. Since IPCC (2013) suggests that the 100-year GWP of methane is uncertain by $\pm 40 \%$, we consider the impact of adjusting our base case methane GWP assumption by $40 \%$. This change would impact the estimated emission savings of each vehicle or furnace option by 5 $7 \mathrm{gCO}_{2} \mathrm{e} / \mathrm{MJNG}$, and power plant options by about 2-3 $\mathrm{gCO}_{2} \mathrm{e} / \mathrm{MJNG}$ (Table 2). The impact of methane GWP on the power plant substitutions is smaller because they avert leaks from local distribution and in-use vehicles and because upstream coal processes emit some methane. Analyses could also be conducted using other time horizons for GWP, or other metrics such as global temperature change potential [IPCC, 2013]. Since the recommended 20-year GWP of methane is 87 [IPCC, 2013], substituting this value for the base 100-year GWP would impact results by 3.5 times the amounts shown in Table 2 for the $40 \%$ change in GWP.

\section{Conclusions}


The results presented here demonstrate that the net emissions impact of natural gas depends strongly on the use for which it is substituted. Far greater emission savings may be achieved by deploying natural gas to replace coal-fired electricity or fuel oil furnaces, rather than cars or buses. New combined cycle power plants provide especially large emission savings if used to replace existing coal electricity. Replacement of old fuel oil furnaces with new natural gas furnaces represents another potent option for achieving $\mathrm{CO}_{2}$ reductions in regions where fuel oil is still widely used.

Despite the uncertainties arising from uncertain upstream emissions and the GWP of methane (Table 2 and Figure 5), the ranking of substitution options in terms of net GHG reduction is likely to be robust because it reflects fundamental differences. Natural gas furnaces and power plants have higher thermodynamic efficiencies than fuel oil furnaces and coal power plants, whereas CNG vehicles have lower efficiencies than gasoline or diesel vehicles. Meanwhile, domestic power plants are not impaired by the methane leaks associated with in-use CNG vehicles, local distribution of natural gas, or overseas shipping of LNG. Furthermore, the coal displaced at power plants is more carbon intensive than the petroleum displaced in vehicles or furnaces. Taken together, these considerations mean that deployments of natural gas to replace coal electricity and fuel oil furnaces are almost certain to achieve more emission reductions than LNG export or CNG vehicles, despite the uncertainties in exact magnitudes of impacts.

These findings have relevance to informing policies that could affect how natural gas is used across sectors. Proposed legislation has sought to expedite the export of natural gas (S. 192, 2013) or subsidize its use in CNG vehicles (H.R. 1380, 2011) - the two uses with the least favorable emissions impacts. To the extent that such efforts redirect natural gas away from power generation and residential heating, they may miss opportunities for emissions savings. 
CNG vehicles and LNG export also require construction of costly new refueling and liquefaction infrastructure that cannot be repurposed as market conditions evolve. By contrast, policies to regulate or price greenhouse gas emissions would tend to favor deployment of natural gas to uses yielding the greatest emissions savings, such as replacement of coal electricity and fuel oil furnaces based on our results.

Upstream emissions from natural gas production and delivery remain highly uncertain and influence impact estimates. If methane leaks from local natural gas distribution have indeed been underestimated [Jackson et al., 2014; Phillips et al., 2013; Wennberg et al., 2012], this would further favor deployment to power plants (which obtain gas directly from major pipelines) over options requiring local distribution. Leaks in local distribution have been studied far less than those from natural gas production, and are expected to be neglected in regulations under development by US EPA that focus instead on methane leaks from natural gas production [Davenport, 2015]. A study in California found local distribution to be the largest and most uncertain contributor to methane leaks from natural gas [Jeong et al., 2014], but a recent national study found lower than expected emissions from local distribution [Lamb et al., 2015]. The uncertainty of emissions from local distribution and their differential nature across deployment options suggest a need for further research to quantify the rate of these leaks.

Rough calculations can be used to compare the potential importance of natural gas deployment choice and of upstream controls for greenhouse gas emissions. Annual natural gas consumption in the U.S. is about 25 trillion MJ [US-DOE, 2013], and our results suggest a range of $74 \mathrm{gCO}_{2} \mathrm{e} / \mathrm{MJ}$ across substitution scenarios (excluding the hybrid scenario) in comparing the net emissions impacts. Thus, each 10 percentage point shift in natural gas deployment could impact $\mathrm{CO}_{2} \mathrm{e}$ emissions by about 190 million metric tons $\mathrm{CO}_{2} \mathrm{e}$, equivalent to about $3 \%$ of all 
U.S. emissions in 2011 [US-EPA, 2013a]. Meanwhile, each 1 percentage point reduction in the natural gas leak rate (equivalent to $6.4 \mathrm{gCO}_{2} \mathrm{e} / \mathrm{MJNG}$ ) would correspond to roughly 160 million metric tons $\mathrm{CO}_{2} \mathrm{e}$ annually. Technologies to control methane emissions associated with natural gas are among the most cost-effective greenhouse gas reduction strategies [Shindell et al., 2012], and the U.S. EPA recently mandated reduced emission completions of hydraulically fractured wells and other emission control measures [US-EPA, 2012a]. Thus, selective deployment of natural gas and reductions in upstream emissions both offer promising pathways to achieving substantial greenhouse gas emission reductions.

The value of emission savings can be monetized based on the social cost of carbon (SCC), which estimates the damage caused by $\mathrm{CO}_{2}$ emissions via climate change. The U.S. Interagency Working Group on the Social Cost of Carbon in 2013 estimated an SCC of $\$ 43 /$ metric ton $\mathrm{CO}_{2} \mathrm{e}$ for 2020 ( $\$ 12-\$ 65$ range depending on discount rate choice). At those rates, the $78 \mathrm{gCO}_{2} \mathrm{e} / \mathrm{MJ}$ net savings achieved by new NGCC power plants replacing existing coal would correspond to 0.34 (0.09-0.51) cents/MJ. By comparison, U.S. electric utilities paid 0.47 cents/MJ for natural gas in 2014 (U.S. EIA Short-term Energy Outlook). Thus, internalizing the greenhouse gas externalities associated with natural gas substitutions could meaningfully influence overall cost considerations.

Future research could extend beyond the fuel cycle greenhouse gas impacts considered here to include the manufacture/construction and disposal phases of the life cycle, as well as other environmental impacts such as air pollution and water consumption. Future work also could apply energy systems modeling to explore how greater deployment of natural gas to each sector affects prices and consumption of natural gas and other fuels in that and other sectors. Such modeling could consider how natural gas competes not only with the fossil fuel uses considered 
here but also with lower-emitting renewable energy options. For example, life cycle emissions for wind electricity are estimated to be less than $20 \mathrm{gCO}_{2} \mathrm{e} / \mathrm{kWh}$ [Weisser, 2007], compared to the 487 or $608 \mathrm{gCO}_{2} \mathrm{e} / \mathrm{kWh}$ estimated here for new or existing natural gas electricity. Thus, any displacement of renewable electricity by natural gas could quickly offset the benefits of replacing coal. Nevertheless, the direct comparisons conducted here across various substitution scenarios highlight the importance of considering the end use of natural gas along with its origin in addressing the net climate impacts of this newly abundant fuel.

\section{Acknowledgments}

This work was funded in part by the Energy and Environment Initiative at Rice University. We acknowledge helpful communications with Andrew Burnham, Ramon Alvarez, Leslie Abrahams, Aranya Venkatesh, and Andrew Henderson in the preparation and revision of this manuscript. Benhang Shi collected data related to natural gas exports and Junqing Zhao conducted preliminary simulations in GREET. Donald Soward designed Figure 1. 


\section{References}

Abrahams, L. S., C. Samaras, W. M. Griffin, and H. S. Matthews (2015), Life Cycle Greenhouse Gas Emissions From US Liquefied Natural Gas Exports: Implications for End Uses, Environ Sci Technol, 49(5), 3237-3245, doi:10.1021/es505617p.

Allen, D. T., V. M. Torres, J. Thomas, D. W. Sullivan, M. Harrison, A. Hendler, S. C. Herndon, C. E. Kolb, et al. (2013), Measurements of methane emissions at natural gas production sites in the United States, Proc. Natl. Acad. Sci. U. S. A., doi:10.1073/pnas.1304880110

Alvarez, R. A., S. W. Pacala, J. J. Winebrake, W. L. Chameides, and S. P. Hamburg (2012), Greater focus needed on methane leakage from natural gas infrastructure, Proc. Natl. Acad. Sci. U. S. A., 109(17), 6435-6440, doi:10.1073/pnas.1202407109.

Brandt, A. R., G. A. Heath, E. A. Kort, F. O'Sullivan, G. Petron, S. M. Jordaan, P. Tans, J. Wilcox, et al. (2014), Methane Leaks from North American Natural Gas Systems, Science, 343(6172), 733-735, doi:10.1126/science.1247045.

Burnham, A., J. Han, C. E. Clark, M. Wang, J. B. Dunn, and I. Palou-Rivera (2012), Life-Cycle Greenhouse Gas Emissions of Shale Gas, Natural Gas, Coal, and Petroleum, Environ Sci Technol, 46(2), 619-627, doi:10.1021/es201942m.

Burnham, A., M. Wang, and Y. Wu (2006), Development and applications of GREET 2.7 -- The transportation vehicle-cycle model, Argonne National Laboratory.

Camuzeaux, J. R., R. A. Alvarez, S. A. Brooks, J. B. Browne, and T. Sterner (2015), Influence of Methane Emissions and Vehicle Efficiency on the Climate Implications of Heavy-Duty Natural Gas Trucks, Environ Sci Technol, 49(11), 6402-6410, doi:10.1021/acs.est.5b00412.

Davenport, C. (2015), Obama Is Planning New Rules on Oil and Gas Industry's Methane Emissions, in New York Times, edited.

Earles, J. M., and A. Halog (2011), Consequential life cycle assessment: a review, Int. J. Life Cycle Assess., 16(5), 445-453, doi:10.1007/s11367-011-0275-9.

Ecofys (2013), International comparison of fossil power efficiency and CO2 intensity - Update 2013.

GAO (2014), Natural Gas: Federal Approval Process for Liquefied Natural Gas Exports; GAO14-762, United States Government Accountability Office. 
Hardisty, P. E., T. S. Clark, and R. G. Hynes (2012), Life cycle greenhouse gas emissions from electricity generation: A comparative analysis of Australian energy sources, Energies, 5, 872897, doi:10.3390/en5040872.

Howarth, R. W., R. Santoro, and A. Ingraffea (2011), Methane and the greenhouse-gas footprint of natural gas from shale formations, Clim. Change, 106(4), 679-690, doi:10.1007/s10584-011$0061-5$.

Hultman, N., D. Rebois, M. Scholten, and C. Ramig (2011), The greenhouse impact of unconventional gas for electricity generation, Environ. Res. Lett., 6(4), doi:044008

10.1088/1748-9326/6/4/044008.

IEA (2011), Are we entering a golden age of gas? Special report in World Energy Outlook 2011.

IEA (2014), Natural Gas Market Outlook, in World Energy Outlook 2014, edited, International Energy Agency.

International_Gas_Union (2014), World LNG Report -- 2014 Edition.

IPCC (2013), Climate Change 2013: The Physical Science Basis, Intergovernmental Panel on Climate Change, Cambridge.

Jackson, R. B., A. Down, N. G. Phillips, R. C. Ackley, C. W. Cook, D. L. Plata, and K. Zhao (2014), Natural Gas Pipeline Leaks Across Washington, DC, Environ Sci Technol, 48(3), 20512058, doi:10.1021/es404474x.

Jeong, S., D. Millstein, and M. L. Fischer (2014), Spatially Explicit Methane Emissions from Petroleum Production and the Natural Gas System in California, Environ Sci Technol, 48(10), 5982-5990, doi:10.1021/es4046692.

Jiang, M., W. M. Griffin, C. Hendrickson, P. Jaramillo, J. VanBriesen, and A. Venkatesh (2011), Life cycle greenhouse gas emissions of Marcellus shale gas, Environ. Res. Lett., 6(3), doi:034014

$10.1088 / 1748-9326 / 6 / 3 / 034014$.

Lamb, B. K., S. L. Edburg, T. W. Ferrara, T. Howard, M. R. Harrison, C. E. Kolb, A. TownsendSmall, W. Dyck, A. Possolo, and J. R. Whetstone (2015), Direct Measurements Show Decreasing Methane Emissions from Natural Gas Local Distribution Systems in the United States, Environ Sci Technol, 49(8), 5161-5169, doi:10.1021/es505116p. 
Luk, J. M., B. A. Saville, and H. L. MacLean (2015), Life Cycle Air Emissions Impacts and Ownership Costs of Light-Duty Vehicles Using Natural Gas As a Primary Energy Source, Environ Sci Technol, 49(8), 5151-5160, doi:10.1021/es5045387.

McJeon, H., J. Edmonds, N. Bauer, L. Clarke, B. Fisher, B. P. Flannery, J. Hilaire, V. Krey, et al. (2014), Limited impact on decadal-scale climate change from increased use of natural gas, Nature, 514(7523), 482-+, doi:10.1038/nature13837.

McKain, K., A. Down, S. M. Raciti, J. Budney, L. R. Hutyra, C. Floerchinger, S. C. Herndon, T. Nehrkorn, et al. (2015), Methane emissions from natural gas infrastructure and use in the urban region of Boston, Massachusetts, Proc. Natl. Acad. Sci. U. S. A., 112(7), 1941-1946, doi:10.1073/pnas.1416261112.

Newell, R. G., and D. Raimi (2014), Implications of Shale Gas Development for Climate Change, Environ Sci Technol, 48(15), 8360-8368, doi:10.1021/es4046154.

NREL (2010), Compressed Natural Gas Transit Bus Experience Survey, Golden, CO.

Peischl, J., T. B. Ryerson, J. Brioude, K. C. Aikin, A. E. Andrews, E. Atlas, D. Blake, B. C. Daube, et al. (2013), Quantifying sources of methane using light alkanes in the Los Angeles basin, California, Journal of Geophysical Research: Atmospheres, n/a-n/a, doi:10.1002/jgrd.50413.

Petron, G., G. Frost, B. R. Miller, A. I. Hirsch, S. A. Montzka, A. Karion, M. Trainer, C. Sweeney, et al. (2012), Hydrocarbon emissions characterization in the Colorado Front Range: A pilot study, J Geophys Res-Atmos, 117, doi:D04304

$10.1029 / 2011 \mathrm{jd} 016360$.

Phillips, N. G., R. Ackley, E. R. Crosson, A. Down, L. R. Hutyra, M. Brondfield, J. D. Karr, K. G. Zhao, and R. B. Jackson (2013), Mapping urban pipeline leaks: Methane leaks across Boston, Environ. Pollut., 173, 1-4, doi:10.1016/j.envpol.2012.11.003.

Shindell, D., J. C. I. Kuylenstierna, E. Vignati, R. van Dingenen, M. Amann, Z. Klimont, S. C. Anenberg, N. Muller, et al. (2012), Simultaneously Mitigating Near-Term Climate Change and Improving Human Health and Food Security, Science, 335(6065), 183-189, doi:10.1126/science.1210026.

Stephenson, T., J. E. Valle, and X. Riera-Palou (2011), Modeling the Relative GHG Emissions of Conventional and Shale Gas Production, Environ Sci Technol, 45(24), 10757-10764, doi:10.1021/es2024115.

US-DOE (2012a), Energy Saver: Furnaces and Boilers. Accessed at http://energy.gov/articles/furnaces-and-boilers. 
US-DOE (2012b), Residential Energy Consumption Survey.

US-DOE (2013), U.S. Natural Gas Consumption by End Use.

US-EIA (2014a), Assumptions to the Annual Energy Outlook 2014, US Department of Energy Energy Information Administration.

US-EIA (2014b), Levelized Cost and Levelized Avoided Cost of New Generation Resources in the Annual Energy Outlook 2014, edited.

US-EIA (2015a), Annual Energy Outlook 2015, US Department of Energy - Energy Information Adminstration.

US-EIA (2015b), U.S. Natural Gas Consumption by End Use, U.S. Department of Energy Energy Information Administration.

US-EPA (2012a), Oil and Natural Gas Sector: New Source Performance Standards and National Emission Standards for Hazardous Air Pollutants Reviews; Final Rule in 40 CFR Parts 60 and 63, edited, p. 111, Federal Register.

US-EPA (2012b), Regulatory Impact Analysis for the Proposed Standards of Performance for Greenhouse Gas Emissions for New Stationary Sources: Electric Utility Generating Units.

US-EPA (2013a), Inventory of U.S. Greenhouse Gas Emissions and Sinks: 1990-2011.

US-EPA (2013b), Standards of Performance for Greenhouse Gas Emissions From New Stationary Sources: Electric Utility Generating Units, edited.

US-EPA (2014a), Carbon Pollution Emission Guidelines for Existing Stationary Sources: Electric Utility Generating Units, edited by U. E. P. Agency.

US-EPA (2014b), Inventory of U.S. Greenhouse Gas Emissions and Sinks: 1990-2012.

Venkatesh, A., P. Jaramillo, W. M. Griffin, and H. S. Matthews (2011a), Uncertainty Analysis of Life Cycle Greenhouse Gas Emissions from Petroleum-Based Fuels and Impacts on Low Carbon Fuel Policies, Environ Sci Technol, 45(1), 125-131, doi:10.1021/es102498a.

Venkatesh, A., P. Jaramillo, W. M. Griffin, and H. S. Matthews (2011b), Uncertainty in Life Cycle Greenhouse Gas Emissions from United States Natural Gas End-Uses and its Effects on Policy, Environ Sci Technol, 45(19), 8182-8189, doi:10.1021/es200930h. 
Venkatesh, A., P. Jaramillo, W. M. Griffin, and H. S. Matthews (2012), Uncertainty in Life Cycle Greenhouse Gas Emissions from United States Coal, Energy Fuels, 26(8), 4917-4923, doi:10.1021/ef300693x.

Victor, D. G. (1992), LEAKING METHANE FROM NATURAL-GAS VEHICLES IMPLICATIONS FOR TRANSPORTATION POLICY IN THE GREENHOUSE ERA, Clim. Change, 20(2), 113-141, doi:10.1007/bf00154171.

Weisser, D. (2007), A guide to life-cycle greenhouse gas (GHG) emissions from electric supply technologies, Energy, 32(9), 1543-1559, doi:10.1016/j.energy.2007.01.008.

Wennberg, P. O., W. Mui, D. Wunch, E. A. Kort, D. R. Blake, E. L. Atlas, G. W. Santoni, S. C. Wofsy, et al. (2012), On the Sources of Methane to the Los Angeles Atmosphere, Environ Sci Technol, 46(17), 9282-9289, doi:10.1021/es301138y. 
Table 1. Efficiency and emissions rates assumed in this study.

\begin{tabular}{|c|c|c|}
\hline & Best Estimate $\left(\right.$ Range $\left.^{a}\right)$ & Source \\
\hline \multicolumn{3}{|l|}{ Vehicle Fuel Economy (miles/gallon) } \\
\hline CNG Civic & 31 & www.fueleconomy.gov \\
\hline Conventional Gasoline Civic & 32 & www.fueleconomy.gov \\
\hline Hybrid Gasoline Civic & 44 & www.fueleconomy.gov \\
\hline CNG Bus & 3.48 & [NREL, 2010] \\
\hline Diesel Bus & 4.33 & {$[N R E L, 2010]$} \\
\hline \multicolumn{3}{|l|}{ Furnace Annual Fuel Utilization Efficiency (AFUE) } \\
\hline Fuel oil: Energy Star & $85 \%$ & US EPA \\
\hline Fuel oil: 1970 s vintage & $65 \%$ & US DOE \\
\hline Natural gas: Energy Star & $95 \%$ & US EPA \\
\hline Electric heat pump: Energy Star & 8.0 HSPF & US EPA \\
\hline \multicolumn{3}{|l|}{ Power Plant Heat Rates (Btu LHV/kWh) } \\
\hline Coal (U.S., existing 2010) & 10,422 & eGRID \\
\hline Coal (U.S., new) & 8,740 & [US-EIA, 2014a] \\
\hline Natural gas (U.S., existing 2010) & 7,905 & eGRID \\
\hline Natural gas (U.S., new advanced combined cycle) & 6,333 & [US-EIA, 2014a] \\
\hline Coal (Japan, existing 2010) & $8,262^{\mathrm{b}}$ & {$[$ Ecofys, 2013] } \\
\hline Natural gas (Japan, existing 2010) & $7,064^{\mathrm{b}}$ & {$[$ Ecofys, 2013] } \\
\hline \multicolumn{2}{|l|}{ Natural Gas $\left(\mathrm{gCO}_{2} \mathrm{e} / \mathrm{MJ}\right)$} & {$[\text { Venkatesh et al., 2011b] }]^{\mathrm{d}}$} \\
\hline Production, processing, and transmission: $\mathrm{CO}_{2}$ & $6.2(3.4-10.1)$ & \\
\hline Production, processing, and transmission: $\mathrm{CH}_{4}$ & $13.2(9.6-16.3)^{\mathrm{c}}$ & \\
\hline Distribution: $\mathrm{CH}_{4}$ & $1.2(0.1-3.2)^{\mathrm{c}}$ & \\
\hline Compression: $\mathrm{CO}_{2} \mathrm{e}$ & $8(4-11)$ & \\
\hline Combustion: $\mathrm{CO}_{2}$ & 50.2 & \\
\hline \multicolumn{2}{|l|}{ Gasoline $\left(\mathrm{gCO}_{2} \mathrm{e} / \mathrm{MJ}\right)$} & [Venkatesh et al., 2011a] \\
\hline Production, refining, and transport: $\mathrm{CO}_{2} \mathrm{e}$ & $18.2(13.3-27.5)$ & \\
\hline Combustion: $\mathrm{CO}_{2} \mathrm{e}$ & 70.2 & \\
\hline \multicolumn{2}{|l|}{ Diesel $\left(\mathrm{gCO}_{2} \mathrm{e} / \mathrm{MJ}\right)$} & [Venkatesh et al., 2011a] \\
\hline Production, refining, and transport: $\mathrm{CO}_{2} \mathrm{e}$ & $17.7(13.0-26.7)$ & \\
\hline Combustion: $\mathrm{CO}_{2} \mathrm{e}$ & 75.3 & \\
\hline \multicolumn{2}{|l|}{ Fuel Oil $\left(\mathrm{gCO}_{2} \mathrm{e} / \mathrm{MJ}\right)$} & [Venkatesh et al., 2011a] \\
\hline Production, refining, and transport: $\mathrm{CO}_{2} \mathrm{e}$ & $17.7(13.0-26.7)$ & \\
\hline Combustion: $\mathrm{CO}_{2} \mathrm{e}$ & 75.7 & \\
\hline \multicolumn{2}{|l|}{ Coal $\left(\mathrm{gCO}_{2} \mathrm{e} / \mathrm{MJ}\right)$} & [Venkatesh et al., 2012] \\
\hline Production and transport: $\mathrm{CO}_{2}$ & $1.9(0.6-3.9)$ & \\
\hline Production: $\mathrm{CH}_{4}$ & $5.5(0.6-17.3)^{\mathrm{c}}$ & \\
\hline \multicolumn{2}{|l|}{ Liquefied Natural Gas $\left(\mathrm{gCO}_{2} \mathrm{e} / \mathrm{MJ}\right)$} & [Abrahams et al., 2015] $^{\mathrm{e}}$ \\
\hline $\begin{array}{l}\text { Landed emissions (includes production, } \\
\text { liquefaction, shipping, and regasification) }\end{array}$ & $39(24-54)$ & \\
\hline \multicolumn{3}{|c|}{$\begin{array}{l}{ }^{\text {a }} \text { Ranges represent } 5^{\text {th }}-95^{\text {th }} \text { percentile for upstream processes [Abrahams et al., 2015; Venkatesh et al., 2011a; b; } \\
2012] \text {. }\end{array}$} \\
\hline \multicolumn{3}{|c|}{${ }^{b}$ Derived from efficiency data. } \\
\hline \multicolumn{3}{|c|}{ 100 -year global warming potential of $36[I P C C, 2013]$ is used to convert $\mathrm{CH}_{4}$ to $\mathrm{CO}_{2} \mathrm{e}$. } \\
\hline \multicolumn{3}{|c|}{ d Species-specific splits provided by A. Venkatesh, personal communication, May 26, 2013.} \\
\hline \multicolumn{3}{|c|}{ ' Based on Table S10, for LNG shipped from Sabine Pass, Louisiana, to Japan. That table assumed a methane } \\
\hline
\end{tabular}


Table 2. Net emissions reduction $\left(\mathrm{gCO}_{2} \mathrm{e} / \mathrm{MJNG}\right)$ per natural gas used under base assumptions and $95^{\text {th }}-5^{\text {th }}$ percentile uncertainty estimates for natural gas upstream emissions, sensitivity to $40 \%$ change in methane GWP, and the break-even leak rate.

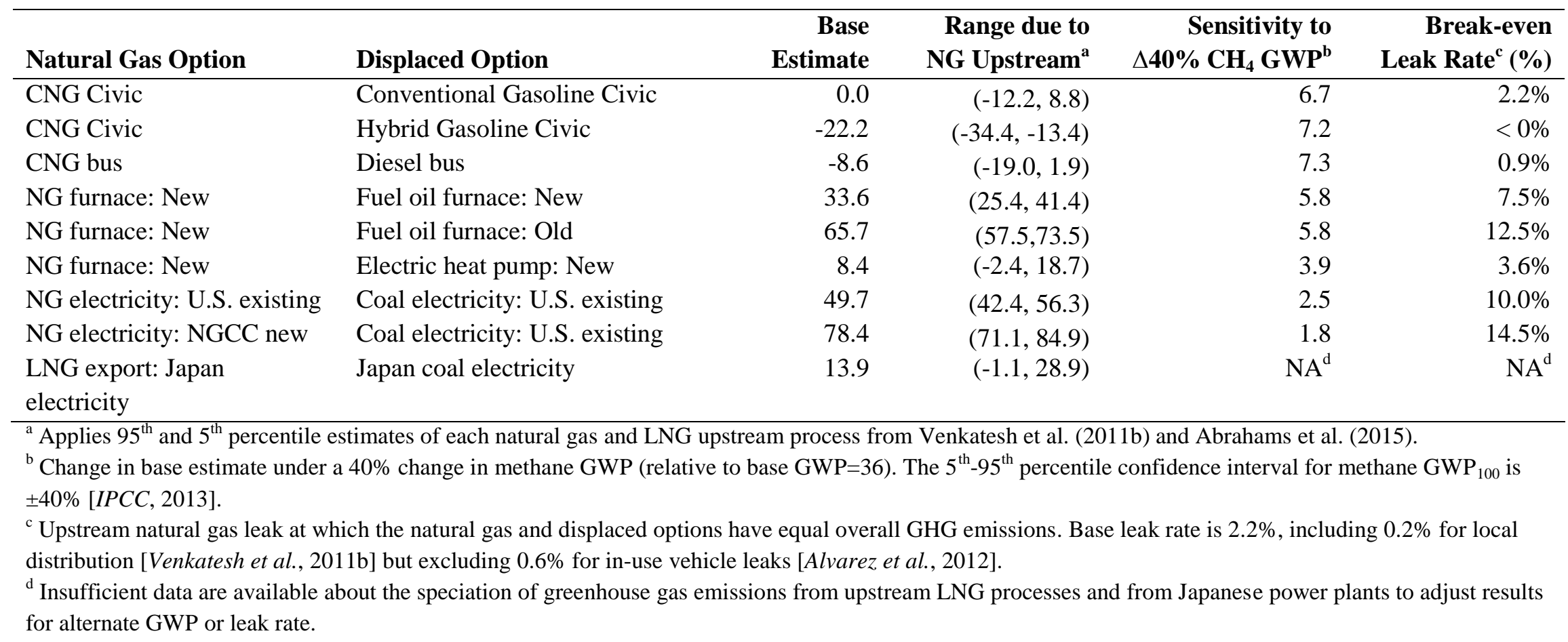




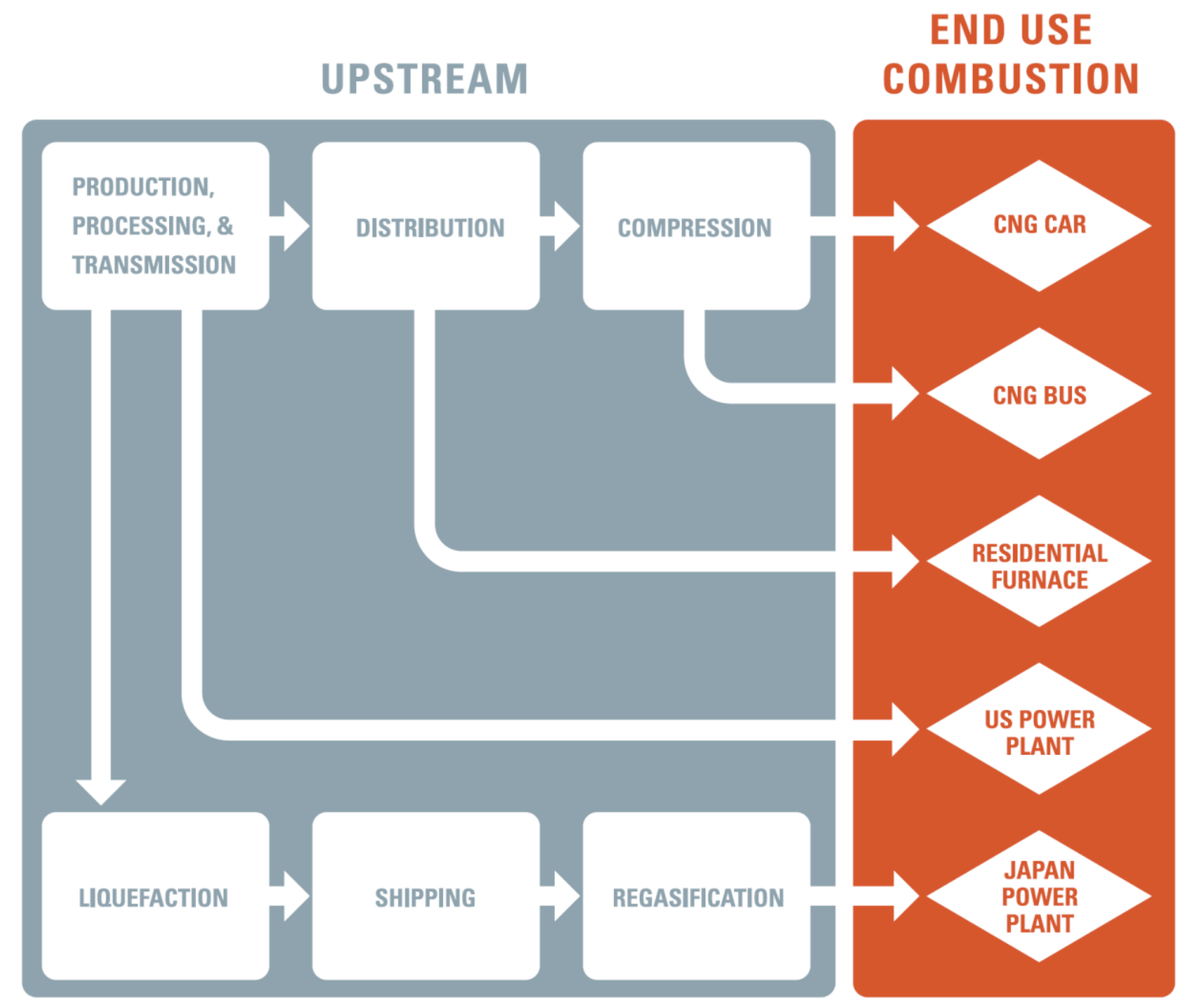

Figure 1. Processes considered in the natural gas fuel cycle (e.g., well-to-wheels or well-towire) for emissions analyses. 


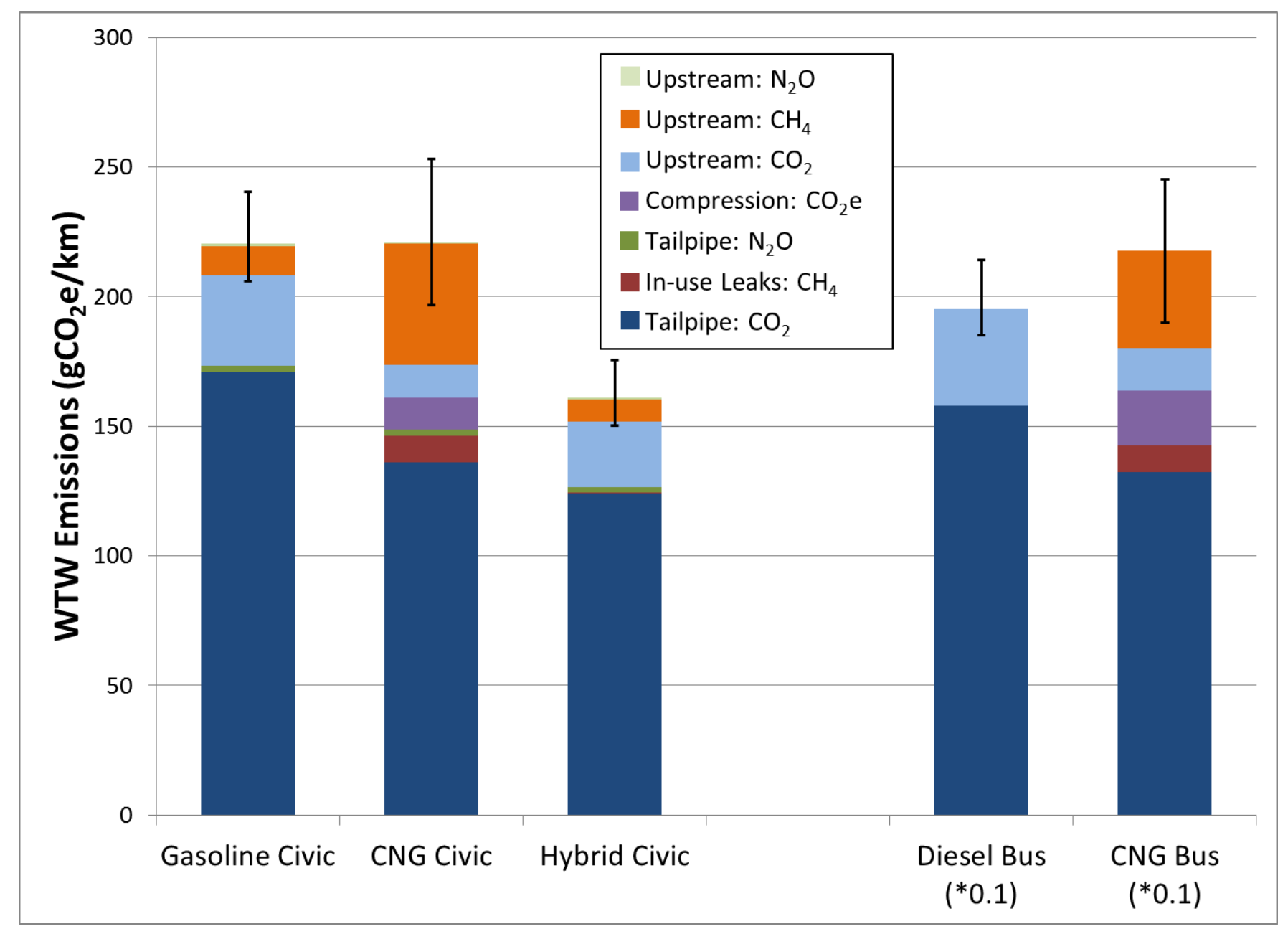

Figure 2. Well-to-wheels emissions of Honda Civics and transit buses (scaled by 0.1), and the uncertainty associated with compression and other upstream processes. 


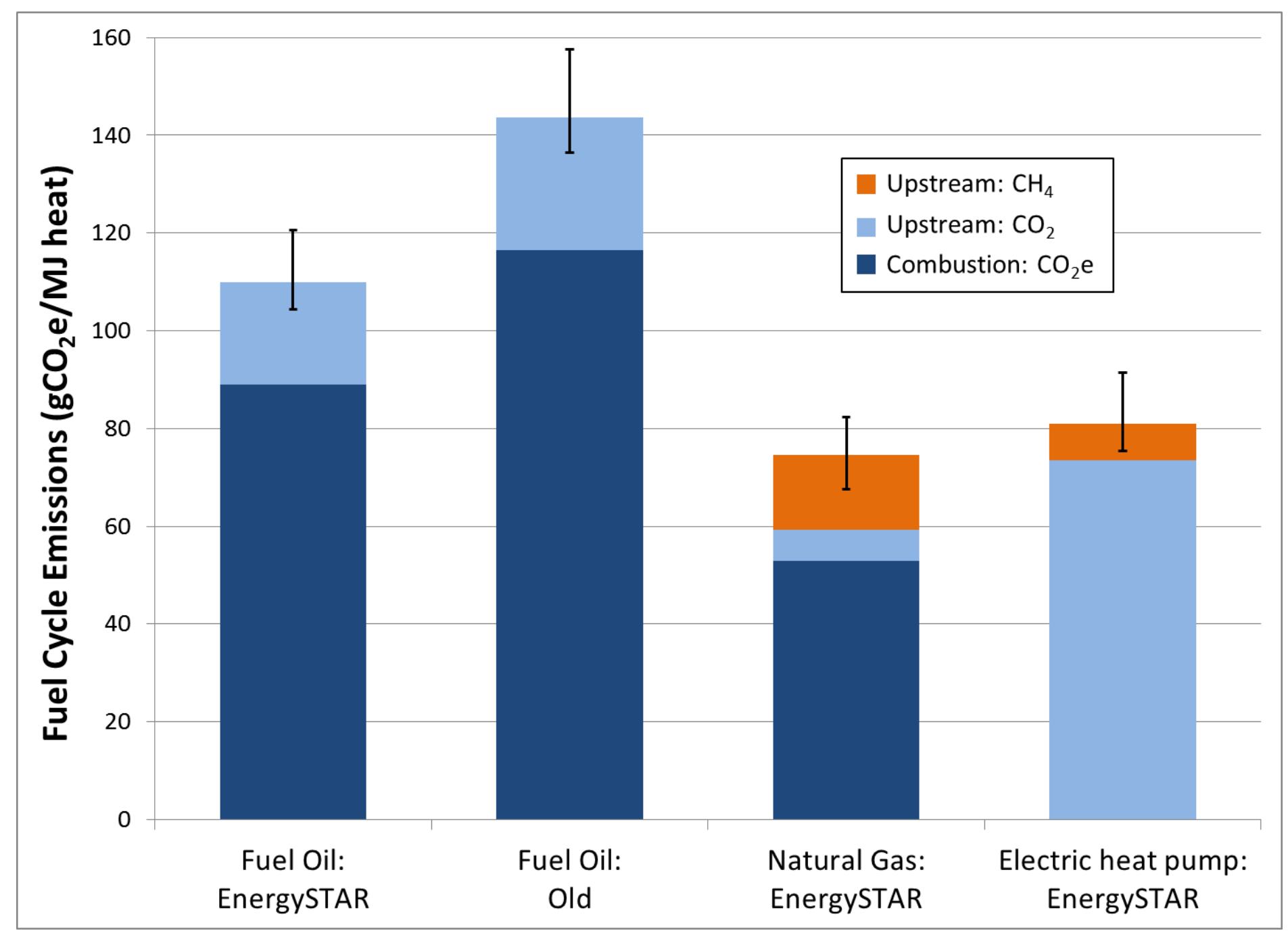

Figure 3. Fuel cycle emissions of residential furnaces per MJ heat output, and the uncertainty associated with upstream processes. 


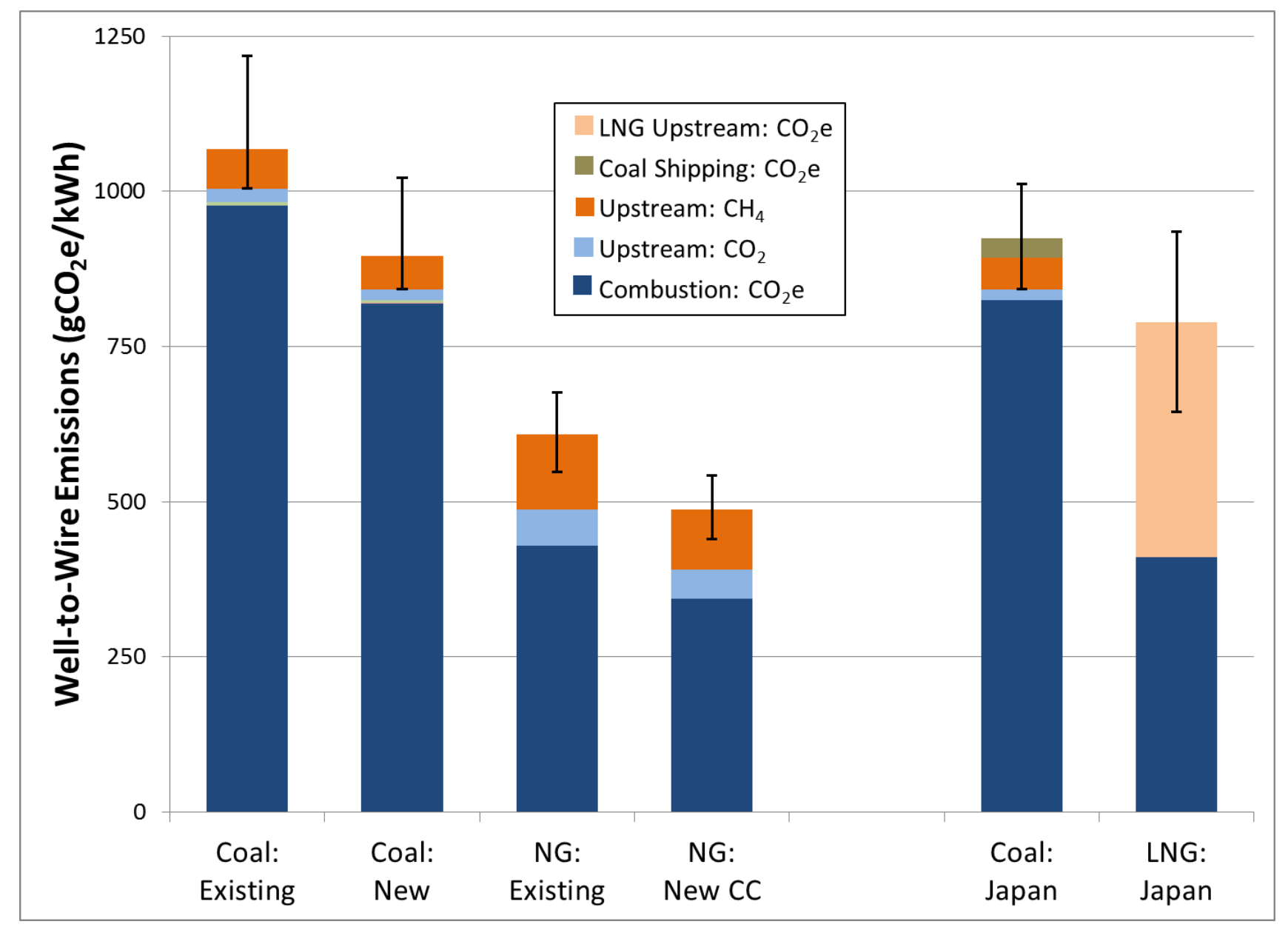

Figure 4. Well-to-wire emissions of coal and natural gas power plants in the United States (left) and powered by imported fuel in Japan (right), and the uncertainty associated with LNG and other upstream processes. 


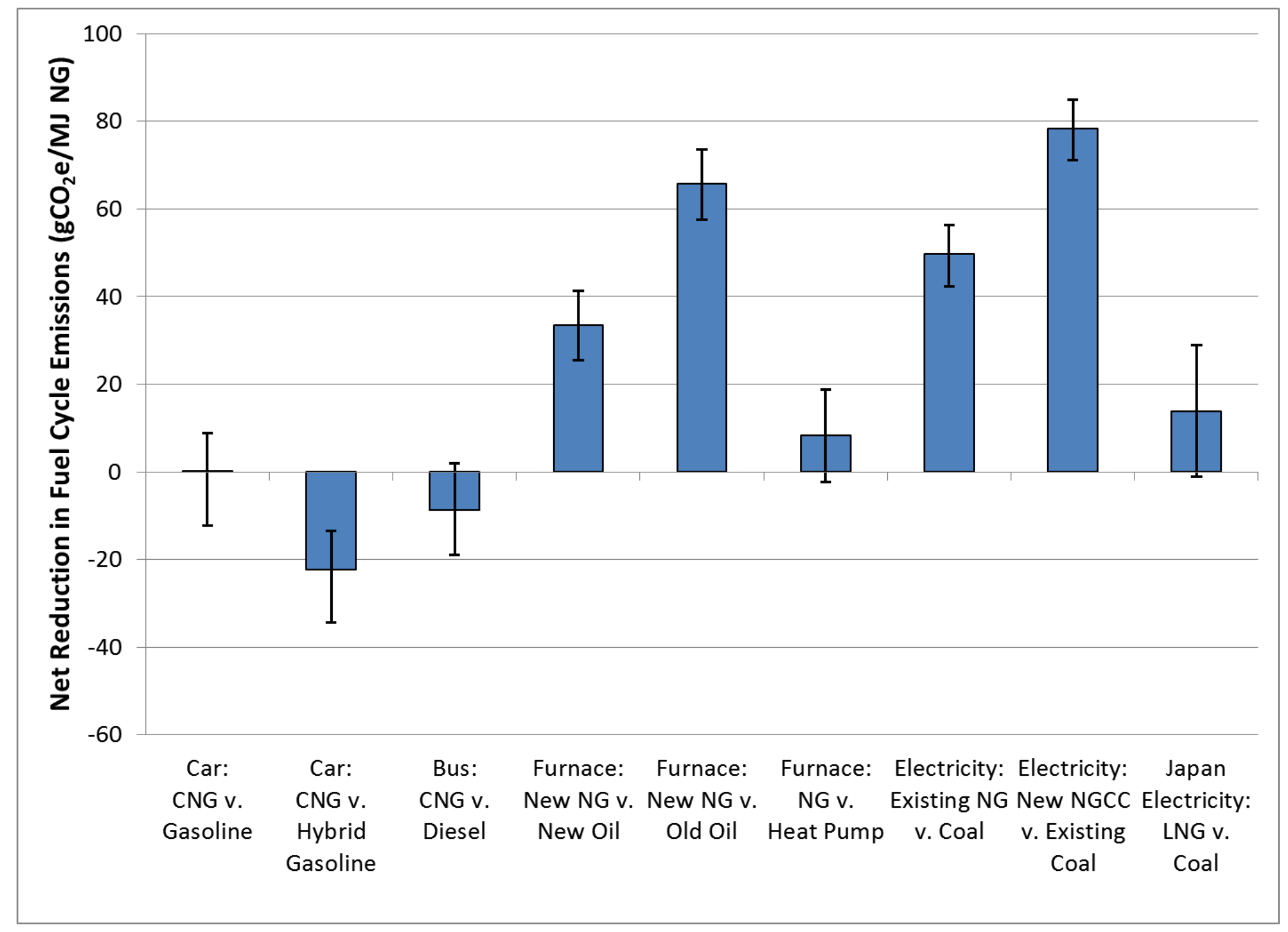

Figure 5. Net emission reductions ( $\mathrm{gCO}_{2} \mathrm{e} / \mathrm{MJNG}$ ) per natural gas used in substitutions for other fossil fuel, and uncertainty due to $95^{\text {th }}-5^{\text {th }}$ percentile uncertainty in natural gas upstream emissions. 